\title{
TRADE-MARKS AND RELATED COMPANIES: A NEW CONCEPT IN STATUTORY TRADE-MARK LAW
}

\author{
LesLIE D. TAggarT*
}

The law of trade-marks grows slowly and without startling changes. It is not a creature of theory, but is fashioned from business and social actualities through necessity by courts and counsel. The legislature has followed this development; legislative enactments are largely codifications of the more desirable trends and developments of existing case law. The new Trade-Mark Act has as one of its purposes "to modernize the trade-mark statutes so that they will conform to legitimate present-day business practice." This is particularly true of the "related companies" provisions.

\section{The "Related Company" Provisions}

The concept of the use of a trade-mark by "related companies" is new in the United States statutes, but it is not new at common law. The provisions in the Lanham Act grew out of business necessities and their recognition by the courts. The legislation was also influenced by the British statute ${ }^{3}$ and by the limitation on assignments of trade-marks.

The pertinent provisions of the Lanham Act are as follows:

Sec. 5. Use by related companies. Where a registered mark or a mark sought to be registered is or may be used legitimately by related companies, such use shall inure to the benefit of the registrant or applicant for registration, and such use shall not affect the validity of such mark or of its registration, provided such mark is not used in such manner as to deceive the public. ${ }^{4}$

Section 45 defines a "related company":

The term "related company" means any person who legitimately controls or is controlled by the registrant or applicant for registration in respect to the nature and quality of the goods or services in connection with which the mark is used.5

The well-established rule of trade-mark law is that a trade-mark means and distinguishes one particular seller's goods from the goods of other sellers; and if it does not distinguish that seller's goods, it is not a trade-mark. This rule describes the primary function of a trade-mark. This function has two results: the owner of the

* LL.B. 1934, Columbia University. Member of the firm of Chandler and Taggart, New York City.

${ }^{2}$ Popularly known as the Lanham Act, approved July 5, 1946, 60 STAT. 427, 15 U. S. C. \$§ro5IIr27 (r946).

${ }^{2}$ H. R. REP. No. 603, 78th Cong., ist Sess. 4 (1943).

${ }^{3}$ The Trade Marks Act, I938, I \& 2 GEo. VI, c. 22; see infra.

(6o STAT. 429, I5 U. S. C. \$1055 (1946).

60 Stat. 443 , I5 U. S. C. \$1127 (1946). 
trade-mark has the financial and other advantages or disadvantages of the consuming public's being able to distinguish his product; and the public has the opportunity of choice-namely, to buy or to reject the product distinguished by the trade-mark. If ordinary purchasers of the goods, buying them in the ordinary way, are likely to be confused by an alleged infringer's mark into believing that they are the goods of the plaintiffs, then the defendant is an infringer; otherwise he is not.

At first glance, the "related company" provisions seem to run counter to this basic function of a trade-mark, by permitting one not the owner of the mark to make or sell (or make and sell) goods bearing the mark. The statute recites certain definite limitations on such use.

\section{Nature of a Trade-Mark Assignment}

At common law, where one other than the original owner of a trade-mark used it, he was either an infringer or he had acquired a right to use the mark. The acquisition of a right to use a mark came either (I) by an assignment, (2) by an independent and honest use of the mark (as illustrated in Section $2(d)$ of the statute, the "concurrent registration" situation), (3) where the original owner had abandoned the mark and the next user adopted it without fraudulent intent, or (4) where the subsequent user acquired permission to use in situations illustrated by the "related company" sections of the Lanham Act. Items 2 and 3 are users adverse to the original owner's use; items I and 4 are users with the permission of the original owner. The decided cases concerning item 4, related companies, are few, while those concerning the assignment type, item $I$, are numerous. While the two types are dissimilar except for the common element of permission of the owner, the courts have been influenced by the rules of assignments in formulating the rules for the use of a trade-mark by related companies.

The two broad rules of assignments are:

I. A trade-mark must be assigned with the good will of the business in which it is used. ${ }^{6}$ This rule is based on the assumption that where a whole business is transferred the new owner will continue it and sell the same goods under the same trade-mark. As a result, the public will obtain the same goods under the trade-mark that it has previously obtained under that mark. There will be no deception of the public. While generally true, the assumption is not always so. A new owner of a business frequently makes considerable changes in a product. ${ }^{7}$ It is generally advisable to inform the public of the assignment to prevent deception; and, under some circumstances, it may be obligatory to do so. ${ }^{8}$

\footnotetext{
'Sce $\$ 10$ of Lanham Act, 6o Stat. 43x, I5 U. S. C. $\$$ raбo (1946); Halliday, Assignments under the Lanham Act, 38 T. M. Rep. 970 (1948).

7 Where the owner of the trade-mark radically changes his own product so that the public may be defrauded, his mark will not be protected. Renaud Sales Co. v. Davis, 22 F. Supp. 703 (D. Mass. 1938); Independent Baking Powder Co. v. Boorman, 75 Fed. 448, 454 (C. C. D. N. J. 19xo).

${ }^{8}$ Alaska Packers' Ass'n v. Alaska Imp. Co., 60 Fed. 103 (C. C. N. D. Cal. I894); Hazlett v. Pollack Stogie Co., 195 Fed. 28 (C. C. A. 3d 1912); for the strict early rule, see Stachelberg v. Ponce, 23 Fed. $43^{\circ}$ (C. C. D. Me. 1885), and Partridge v. Menck, 2 Sandf. Ch. R. 622 (N. Y. I848).
} 
2. If the owner assigns the trade-mark without the good will of the business (known as "an assignment in gross"), the assignment transfers nothing to the assignee $^{9}$ and may constitute an abandonment by the assignor. ${ }^{10}$

In these two rules of assignments, we find one basic concept: namely, that the court will not protect a trade-mark in the hands of an assignee where there is a deception of the public in the assignee's use of the mark. The corollary is that where the assignee's use does not deceive the consumer the assignment is good and the trade-mark will be protected on behalf of the assignee.

\section{Types of "Related Company" Situations}

The same basic reasoning was applied by the courts to "related company" situations prior to the Lanham Act. However, "related company" situations differ considerably from assignments. In an effective assignment, the assignor makes a complete conveyance of all his rights. On the contrary, in a "related company" situation, there is not a complete assignment, nor in fact is there any assignment. What is granted is a permission to use. This permission to use is girded with the restrictions placed on assignments. To be effective, a "related company" arrangement should constitute a "controlled license," with the right to the mark remaining in the owner and the "controlled licensee" making a specified use of the mark. The following are illustrations of "controlled licenses" of trade-marks:

Subsidiary companies. With the growth of business, it was often found essential for a business to be set up in more than one legal unit. Such necessity had no connection with trade-mark problems. Yet it was convenient and often necessary to have one trade-mark used by the whole business. In Keebler Weyl Baking Company v. J. S. Ivins' Sons, Inc., ${ }^{11}$ various subsidiary corporations of one business unit used the trade-mark "Club Cracker" for soda crackers. In an infringement suit, the defendant pleaded that, since various subsidiaries used the mark, it did not indicate to the public one source of origin of the soda crackers, but various sources of origin, and that the trade-mark therefore was invalid. The court stated:

Keeping pace with industrial and business development the law has advanced a considerable distance from the earlier decisions which were made when small individual businesses, personally owned and personally managed, were the rule rather than the exception. ${ }^{12}$

The court then held that the validity of a trade-mark is not affected by its use by co-subsidiaries of the owner. The court pointed out that the subsidiary which owned the trade-mark supervised the manufacture of the crackers by the other subsidiaries, and had each of them manufacture in the same way. Had the business been in one corporation, the fact that the crackers were manufactured in different factories would

${ }^{\circ}$ Corr v. Oldetyme Distillers, II8 F. 2d 9 I9 (C. C. P. A. I94I).

${ }^{10}$ Mayer Fertilizer \& Junk Co. v. Virginia-Carolina Chem. Co., 35 App. D. C. 425 (1910); Buckcye Brewing Co. v. Burger Bros. Co., 28 U. S. P. Q. 235, 237 (1936).

${ }_{11} 7$ F. Supp. 2 II (E. D. Pa. r934).

${ }^{12} \mathrm{Id}$. at $2 \mathrm{r} 4$. 
not have affected the validity of the trade-mark. That the business was organized in several corporations properly did not change the court's recognition that the whole was one business unit and that the trade-mark could properly be used by each part of the whole. One salient feature is that the plaintiff was required to show control of manufacture and of the nature and quality of the goods.

Harking back to the assignment analogy, Judge Kirkpatrick said:

I can see no imposition upon the public, no abandonment, and no other element which impairs a trade-mark right when the corporation which owns it, which in turn is owned by a general control, permits other corporations under the same general control to use the mark upon an identical product which they produce in accordance with the owner's directions and instructions. ${ }^{13}$

However, the Trade-Mark Act of $1905^{14}$ did not permit the registration of a mark not used exclusively by the legal entity applying for its registration. In Ex parte United States Steel Corporation, ${ }^{1 \bar{j}}$ that corporation, a holding company and not an operating company, sought to register "U. S. S.", its initials, as a trade-mark for use by its subsidiaries. Since the applicant did not use the trade-mark it was not registrable, and none of the subsidiaries could register it because none used it exclusively. Nevertheless, the trade-mark would undoubtedly have been protected by the courts.

Further manufacturing. Some concerns with well-known products found that further processing was necessary and, for various reasons, it was not practical for them to do that further processing themselves. Yet it was important and sometimes imperative for them to control the products during the further-processing and to have the trade-mark used to distinguish and sell the finished product.

In B. B. \& R. Knight, Inc. v. W. L. Milner \& Company, ${ }^{16}$ the plaintiff owned the very old and respected trade-mark "Fruit of the Loom," which distinguished its cotton piece goods. For a number of years it had permitted manufacturers to buy its piece goods and, under its complete supervision and control, to process the piece goods into consumer goods-shirts-and sell them as "Fruit of the Loom" shirts. In this case, the defendant had purchased "Fruit of the Loom" piece goods, and, wholly independent of plaintiff, had made them into shirts and sold them under the "Fruit of the Loom" label. Defendant argued that its shirts were made from "Fruit of the Loom" piece goods and therefore were "Fruit of the Loom" shirts. It argued further that plaintiff had licensed its trade-mark, that it was not the manufacturer of "Fruit of the Loom" shirts, and there were no trade-mark rights remaining in the plaintiff. The plaintiff showed that it had complete control over this shirt production of its licensee-manufacturers, and the court commented on this control in the following highly significant language:

${ }^{13}$ Ibid.

${ }^{14} 33$ Stat. 724 (I905), as amended, 52 STAT. 638 (1938), I5 U. S. C. \$8I et seq. (1946).

1523 U. S. P. Q. I45, 24 T. M. Rep. 597 (I934).

${ }^{10}{ }_{28}$ Fed. 816 (N. D. Ohio I922). 
During this period of 30 years, B.B. \& R. Knight, Inc., had permitted and licensed manufacturers of men's shirts and other garments to use and apply this trade-mark, but had done so only on condition that the manufacturer join with the owner of the trade-mark in guaranteeing, not only the quality of the goods, but the workmanship, design, and reliability of the finished article. They have selected only reliable manufacturers of high standing, and have required such manufacturers to join with the owner of the trade-mark in such warranty and guaranty, and also in an obligation to refund the purchase price if the ultimate user was for any reason dissatisfied with the article. The obligation to refund the money was one to be performed by both the manufacturer of the article and by the maker of the cloth. ${ }^{17}$

The result of the decision was to establish the rule that where a trade-mark owner, through contract, completely controls the nature and quality of a finished product, though manufacture is completed by another, with the result that the finished product means to the consumer that it is the product of or is sponsored by the owner of the mark, the courts will protect the trade-mark. ${ }^{18}$

Bottlers. The "bottlers" cases are another variety of the further-processing situation. This situation is well illustrated by Coca-Cola Company v. Bennett ${ }^{10}$ and CocaCola Company v. J. G. Butler \& Sons. ${ }^{20}$ The Coca-Cola Company manufactures a syrup in Atlanta, Georgia. It would be impractical for it to supply the bottled product directly to the entire United States market from that city. It would be further impossible for it or any other company in the same field to acquire sufficient capital to have bottling plants throughout the United States. In addition, it is highly desirable for a local person or group to handle local promotion, selling, and other local matters. Accordingly, the Coca-Cola Company (like other beverage companies) supplies syrup to local bottlers, directly or through distributors, under contracts which require the addition of various ingredients to the syrup under detailed instructions. The local bottler follows the instructions and then sells the bottled product under the trade-mark. The owner of the mark very naturally does not want anyone but itself to have any interest in the trade-mark, except the temporary rights specifically set forth in the agreements with the bottlers. The courts have repeatedly confirmed the ownership and validity of trade-marks in such situations, and have approved this form of doing business.

The Supreme Court, in Bacardi Corporation of America v. Domenech, ${ }^{21}$ has similarly recognized the validity of other types of business situations. Compania Ron Bacardi, S. A., a Cuban corporation, had for many years sold "Bacardi" rum in Puerto Rico and elsewhere. The petitioner in the action was permitted by the Cuban corporation to manufacture and sell rum in Puerto Rico under the "Bacardi" trade-marks and labels. Chief Justice Hughes outlined the salient facts as follows:

\footnotetext{
${ }^{17} \mathrm{Id}$. at $8 \mathrm{r} 7$.

${ }^{18}$ See also H. Freeman \& Sons v. Huyck \& Son, 7 F. Supp. 971 (N. D. N. Y. 1934).

10238 Fed. 513 (C. C. A. 8th 1916).

${ }^{20} 229$ Fed. 224 (E. D. Ark. 1916).

${ }^{21} 3$ II U. S. 150 (1940).
} 
Bacardi rum has always been made according to definite secret processes, has been extensively advertised and enjoys an excellent reputation. Under petitioner's agreement with the Cuban corporation, all rum designated by the described trade marks and labels was to be manufactured under the supervision of representatives of the Cuban corporation and to be the same kind and quality as the rum that the latter manufactured and sold. ${ }^{22}$

The Puerto Rican government had enacted legislation which prevented petitioner from manufacturing rum in Puerto Rico and selling it under a trade-mark which had "been used previously . . . outside the Island of Puerto Rico," unless the petitioner had manufactured and sold rum under such mark in Puerto Rico before a certain date. Under the statute, the Court said,

... petitioner is prohibited from the use of its trade marks, although valid and duly registered and although the product to which they are applied is otherwise lawfully made and the subject of lawful sale, solely because the marks had previously been used outside Puerto Rico and had not been used on spirits manufactured in Puerto Rico, or exclusively in continental United States, prior to February $1,1936 .{ }^{23}$

The statute was declared unconstitutional. In order to reach this result, the Court was obliged to determine the validity of the "Bacardi" trade-mark and to recognize the propriety of the arrangement between the Cuban corporation and the petitioner.

Although it was decided after the Lanham Act became effective (July 5, 1947), the case of E. I. duPont de Nemours \& Company v. Celanese Corporation of America $^{24}$ is illustrative of the continuation of this development of "controlled licenses." DuPont petitioned to cancel Celanese Corporation's registration of "Celanese" as a trade-mark for dyestuffs. DuPont averred that Celanese Corporation had entered into a "non-exclusive license" with a third party "to employ said trade-mark in connection with dyestuffs," that the third party had advertised its "Celanese" dyestuffs without any reference to Celanese Corporation, that the third party shipped its Celanese dyestuffs to its customers without any reference to Celanese Corporation, that "Celanese" on dyestuffs had ceased to denote origin in Celanese Corporation, that "Celanese" was no longer a trade-mark for dyestuff and had been abandoned. In the agreement between Celanese Corporation and the third party, there was the usual contractual recognition of the validity and ownership by Celanese Corporation of "Celanese"; in addition there were provisions for a set of standards and for inspection by representatives of Celanese Corporation of the third party's dyestuffs, a requirement that all advertising show Celanese Corporation as the owner of the trade-mark, and a provision that Celanese Corporation was to approve all advertising. Despite the contract, some of third party's advertisements supported duPont's pleadings. Celanese moved to dismiss the petition. The examiner of interferences granted the motion, the Commissioner of Patents affirmed, and the

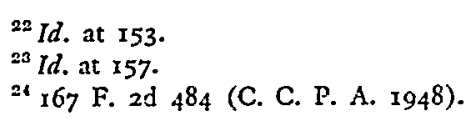


Court of Customs and Patent Appeals affirmed (with one dissent). The court considered abandonment the essential question, as required under the cancellation section of the applicable 1905 Act. On this point it stated:

$\ldots$ it was well settled that one who assigns his trade-mark with or without the business with which it has been used, abandons his mark, but that a license agreement, not merely a naked license to use, where the licensor expressly reserves his right to continue the use of the mark and which license agreement provides that the agreement may be terminated by the licensor, is not an abandonment of its registered mark. ${ }^{25}$

After reviewing the facts, the court held:

It is obvious, therefore, that the license agreement is not a naked license agreement, and that appellee has not abandoned its mark within the purview of section 13 of the TradeMark Act of February 20, 1905, as argued by counsel for appellant. ${ }^{28}$

The breach of the license agreement by, the advertisements referred to was not considered important since duPont had not averred that "the public or anyone else was deceived."

The dissenting judge pointed out (I) that there was no showing that Celanese Corporation had exercised the right of supervision and control of the third party's product and advertising; (2) that a court may infer abandonment from the lack of control over the third party's manufacture and advertising; (3) that a court may infer abandonment and also deception of the public from breaches of the type admitted by the motion to dismiss. It is suggested that in preparing a related-company agreement, and in advising as to its strict enforcement, Judge O'Connell's dissent be carefully studied.

The references to the contract between Celanese Corporation and the third party do not indicate that the third party was required to give notice to the public on its packages and labels that "Celanese" was the trade-mark of Celanese Corporation. Even if this was omitted from the contract, the decision does not indicate its necessity in a "controlled license" situation. However, in "controlled licenses" of this type, it is better practice for the legal draftsman to require such notice on packages and labeling. ${ }^{2 \pi}$

Although this case was decided after the Lanham Act became effective, the majority found it unnecessary in view of their opinion to consider the relatedcompany sections, and the dissenting judge did not consider them applicable under Section $46(a)$.

These three main illustrative types of "controlled licenses" show that the owner of the trade-mark need not be the manufacturer or the seller of the goods, provided he in fact controls the nature and the quality of the goods.

\footnotetext{
25 Id. at 487 .

${ }^{20} \mathrm{Id}$. at 488 .

${ }^{37}$ See note 8 supra.
} 
By contrast, a "license in gross," i.e., a license of a trade-mark without a transfer of good will or of control over the use of the mark, is invalid ${ }^{2 s}$ for the same reason that invalidates an assignment in gross.

The Fisk case ${ }^{29}$ illustrates the pitfalls in setting up a "controlled license." There, the plaintiff had conducted a teachers' employment agency in Boston for many years under the name "Fisk Teachers' Agency." By written contract, it permitted other individuals to establish independently owned and conducted "branches" throughout the country under that name. When the Denver "representative" broke away, refused to make payments to the plaintiff, and established his competing concern under the same name, the court refused to protect the plaintiff for the reason that the plaintiff had, for a monetary consideration, permitted and induced the public to believe that each "Fisk" teachers' agency was a part of one national business. To paraphrase the language of the Lanham Act, the court held that the plaintiff did not control each local representative "as to the nature and quality of the services in connection with which the mark is used."30

\section{History of the Statutory Provisions}

The case law outlined above was the background for the provisions in the various "related company" sections in the bills which finally resulted in the sections of the Lanham Act above quoted. In the $193^{8}$ bill the section read:

Sec. 6. Use by Related Companies. Where the trade-mark sought to be registered is used by subsidiary or related companies, the application shall so state, and such use shall be deemed exclusive; and use of registered trade marks by companies subsidiary or related to the registrant shall not affect the validity of such trade-mark or of its registration. ${ }^{31}$

There was no definition of "related company" in that bill. The stress was on subsidiary companies. The section on assignments partially explains the restricted language, since that section permitted the assignment (and inferentially the licensing) of a trade-mark either "with or without the good will of the business." This "related company" section covered the situation in the United States Steel case and in part the situation in the Keebler Weyl case. Although this provision for assignments was continued in the 1939 bill," "related companies" began to take on a more detailed contour. The section was broadened by the addition of the words "or by the members of an association"33 and, more important, by the following definition:

\footnotetext{
${ }^{38}$ Falk v. American West Indies Trading Co., 180 N. Y. 445, 73 N. E. 239 (1905); American Broadcasting Co. v. Wahl Co., I2I F. 2 d 412 (C. C. A. 2 d I94I). See also Purity Cheese Co. v. Frank Ryser Co., $x 53$ F. 2d 88 (C. C. A. 7th 1946 ).

${ }^{20}$ Everett D. Fisk \& Co. v. Fisk Teachers' Agency, 3 F. 2d 7 (C. C. A. 8th I924).

${ }^{30}$ See also Federal Systems of Bakeries v. Bachrach, I3 T. M. Rep. 429 (W. D. Pa. I923).

${ }^{31}$ H. R. 9041, 75th Cong., 3d Sess. (1938).

32 H. R. 4744 , 76 th Cong., Ist Sess. (1939).

${ }^{33}$ Id. $\$ 5$. This seems redundant in view of the action in H. R. 4744 under the heading, Collective and Association Marks Registrable.
} 
The term "related company" means any individual, partnership, or person within the definition above where by stock ownership, contractual relationship, or otherwise, the nature and quality of the goods upon which the mark is used is controlled by the regis. trant. ${ }^{34}$

For the first time, the term "contractual relationship" is included. The "related company" definition under this bill covered the "Fruit of the Loom" case and the bottlers' cases discussed above.

In the $1939-1940$ bill, ${ }^{35}$ the assignment provision had been changed to provide for assignment "upon such terms and conditions as the parties may agree." Although parties could agree to assign without good will, that would have been dangerous in view of the case law on assignment, and we find "assignment" law coming into the "related company" section with the following common-law provision: "Such mark [i.e., a mark used by related companies] shall not be used in such manner as to deceive the public." The definition of "related company" is continued with minor changes.

In succeeding bills similar provisions are included, and in the 1943 bill, ${ }^{30}$ language practically identical with that of the Lanham Act was set forth both for the section on use by related companies and in the definition. The words "subsidiary," "members of an association," "holding," and "parent" are eliminated. The remaining words are "related companies." Prior to such elimination, it was not clear whether only the parent or holding company could be the registrant of the mark or whether the subsidiary or a company operating under a contractual relationship could be the registrant. However, the words "who controls or is controlled by the registrant or applicant for registration" clarified the bill, and the present statute, on that point.

After the I943 bill, the only change on this point was the insertion in Section 5 of the word "legitimately." The Department of Justice does not appear to have appreciated the legitimate purposes of the "related companies" provisions, and indicated that they might be used as a screen to circumvent the laws against monopoly. "Legitimately" was inserted to assure the Department of Justice that the related companies were not such a subterfuge. ${ }^{37}$

\section{The Brittsh "Registered User"}

Since the British law of trade-marks is also founded on the common-law concept of use, as opposed to the civil-law rule of rights based on registration, British statutes and precedents in British courts are frequently considered in this.country. The British also have considered the problem of "controlled licensing" of marks, and

${ }^{34} I d . \$ 46$.

${ }^{35}$ H. R. $66 \mathrm{I} 8$, 76th Cong., 3d Sess. (1940).

${ }^{80}$ H. R. 82, 78th Cong., rst Sess. (1943).

${ }^{37}$ For a discussion of trade-marks and the antitrust laws, see Taggart, Trade-Marks: Monopoly or Competition? 43 MicH. L. Rev. 659 (I945), 35 T. M. Rep. 25 (1945). 
revised their statutory law in $193^{38}$ by providing for the entry of a "registered user" of a trade-mark.

Where it is desired to provide for the "permitted use" of a trade-mark by a third party, the registered owner of the mark and the proposed "registered user" file a joint application accompanied by a Statement of Case which shows "particulars of the relationship, existing or proposed, between the proprietor and the proposed registered user, including particulars showing the degree of control by the proprietor over the permitted use which their relationship will confer . ."39 and other details. Generally speaking, the "relationship" is of two kinds: (I) The relationship which exists by virtue of the fact that the owner of the trade-mark owns sufficient share capital of the proposed registered user to control all the activities of the registered user; or (2) the relationship which exists by virtue of an agreement which provides for the manner of use of the mark by the registered user. If the Registrar is satisfied that the use of the mark by the registered user is not contrary to the public interest, he enters the registered user as such.

The British statute does not by its language require the registrant to control or be controlled "in respect to the nature and quality of the goods or services in connection with which the mark is used,"10 but it appears that the Patent Office, which is given rather wide discretion under the pertinent section, insists that where the

${ }^{38}$ The Trade Marks Act, 1938, I \& 2 Gro. VI, c. 22.

${ }^{30} \mathrm{Id}$. $\$ 28$. Some pertinent portions of $\$ 28$ of the British statute are set forth here:

"Sec. 28 (I). Subject to the provisions of this section, a person other than the proprictor of a trade mark may be registered as a registered user thereof in respect of all or any of the goods in respect of which it is registered (otherwise than as a defensive trade mark) and either with or without conditions or restrictions.

"The use of a trade mark by a registered user thereof in relation to goods with which he is connected in the course of trade and in respect of which for the time being the trade mark remains registcred and he is registered as a registered user, being use such as to comply with any condition or restrictions to which his registration is subject, is in this Act referred to as the 'permitted use' thereof.

"(2) The permitted use of a trade mark shall be deemed to be use by the proprietor thereof, and shall be deemed not to be use by a person other than the proprietor, for the purposes of section twenty-six of this Act and for any other purpose for which such use is material under this Act or at common law.

"(4) Where it is proposed that a person should be registered as a registered user of a trade mark, the proprietor and the proposed registered user must apply in writing to the Registrar in the prescribed manner and must furnish him with a statutory declaration made by the proprietor, or by some person authorised to act on his behalf and approved by the Registrar,-

"(a) giving particulars of the relationship, existing or proposed, between the proprietor and the proposed registered user, including particulars showing the degree of control by the proprietor over the permitted use which their relationship will confer and whether it is a term of their relationship that the proposed registered user shall be the sole registered user or that there shall be any other restriction as to persons for whose registration as registered users application may be made;

"(b) stating the goods in respect of which registration is proposed;

"(c) stating any conditions or restrictions proposed with respect to the characteristics of the goods, to the mode or place of permitted use, or to any other matter; and

"(d) stating whether the permitted use is to be for a period or without limit of period, and, if for a period, the duration thereof;

"and with such further documents, information or evidence as may be required under the rules or by the Registrar."

For statute, regulations, and forms, see Bray AND Underhay, THE TRAdE Marks Acr, I938, with Annotations (1938).

${ }^{40}$ Sec. 45 of Lanham Act, 6o Stat. 443, I5 U. S. C. \$Ir27 (1946). 
"relationship" depends upon an agreement, as in (2) above, the agreement should provide for this kind of control.

The British provisions for the entry of a registered user are considerably more specific than the provisions under the Lanham Act, ${ }^{41}$ particularly since the "relationship" is scrutinized by the Trade Marks Office and is made the subject of a specific entry on the Register.

Although the British Board of Trade's Report ${ }^{42}$ was available prior to the introduction of H. R. 904I on January I9, I938, and the Trade Marks Act, 1938, was available shortly thereafter, the internal evidence in $\mathrm{H}$. R. 904I does not indicate much influence of the British "registered user" provisions. ${ }^{43}$ A seriatim examination of the various Lanham bills shows an increasing similarity, whether intentional or not, to the British statute. Although many of the lawyers interested in the Lanham bills were familiar with the British statute, no definite statement can be made as to its influence on the Lanham Act, despite a similarity in the result. It is believed that the similarity resulted in part from the efforts of lawyers, similarly trained in the common law, to solve comparable problems. ${ }^{44}$

\section{Procedure in Registration}

The Patent Office has issued Rule 7.8, "Use by predecessor or by related companies," pursuant to Section $4 \mathrm{I}$ of the Lanham Act. ${ }^{45}$ The requirement of "exclusive use" by the applicant is modified as required by Section 5 . The second paragraph of the rule provides:

Where the mark sought to be registered is legitimately used by one or more related companies at the time of the filing of the application, the declaration (Rule 7.4) must recite exceptions to the averment of the exclusive right to use the mark, stating the nature of such related companies and, if practicable, the names and addresses. ${ }^{46}$

In practice, the Patent Office makes no attempt to determine whether the mark is used "legitimately," on the plea that it is not equipped to do so. However, since a registration is "constructive notice of the registrant's claim of ownership" (Section 22) and since the Patent Office is the guardian of the public interest, ${ }^{47} a$ "related company" registration can properly be considered a recognition of the legitimate

11 For discussion of information required by United States Patent Office, sce the discussion under "Procedure in Registration," infra.

12 Board of Trade, Report of the Departmental Committee on the Law and Practice Relatino to Trade Marks (1934).

${ }^{43}$ Under British law prior to the Trade Marks Act, 1938, there had been no development in the law similar to that in the American courts. "Licenses to use a trade mark and assignments without the goodwill of a business or part of it were practically prohibited." BRAY AND UNDERHAY, op. cit. supra note 39, at xiv. The same authors, commenting on the "registered user" section, state that: "Under the former legislation and at common law, a license by the proprietor of a trade mark to another party to use the mark on goods other than those of the proprietor was considered to be a form of deception which invalidated the registration and put an end to common law rights." $I d$. at 41 .

"No reported decisions are available on "registered user" which might assist American lawyers.

${ }^{45}$ Rules of Praktice in Trade-Mark Cases (U. S. Dep't of Commerce, 1947). These rules set forth the methods to be followed in preparing, filing and prosecuting applications to rcgister.

"Id. at I3.

${ }^{17}$ Frankfort Distilleries, Inc. v. Dextora Company, 103 F. 2d 924 (C. C. P. A. 1939). 
use of the mark, with the right of an interested party to attack its legitimacy in any proper forum. ${ }^{48}$

The phrase "stating the nature of such related companies" in Rule 7.8 is ambiguous, and is interpreted as meaning the nature of the relationship between the companies in respect to the mark involved. It seems advisable to set forth such relationship in detail, so that it would be more difficult for an attacker of the mark to sustain a claim that the application gave the Patent Office insufficient information to make a proper determination, and the attendant claim of fraud based on such insufficiency; but the Patent Office has taken the position that a brief recital of the relationship is sufficient for its purpose. The first paragraph of Rule 7.8 indicates the reason. This paragraph reads in part:

If the first use, the date of which is required by paragraph $(\mathrm{g})$ or $(\mathrm{h})$ of Rule $7 \cdot 3$, was ... by a related company ... and such use inures to the benefit of the applicant, the date of such first use may be asserted with a statement that such first use was . . . by the related company.... The Office may require further details and additional proof showing that such use inures to the benefit of the applicant. ${ }^{49}$

The Patent Office stresses the date of first use. However, it has the power under the statute and its rules to make sure that it has the facts which show that a use "inures to the benefit of the applicant."

The issuance of a registration by the Patent Office, under prior law and the present statute, is presumptively correct and will be considered so by a court unless clearly wrong. ${ }^{50}$ A registrant is entitled to have the benefit of this valuable presumption. It is respectfully submitted that the Patent Office should encourage and require an adequate showing of facts so that this presumption shall continue as to related-company registrations.

Rule 7.8 requires a statement, "if practicable," of the names and addresses of the related companies. In most instances such a showing is practicable and should be given. The bottler's situations are recognized as generally impracticable.

The Lanham Act came into effect on July 7, 1947. As far as related companies are concerned, it is prospective in operation. The question arises as to what should be done concerning related-company situations which were in existence prior to that date. Is a pre-July 7 , I947, registration of a mark which had been used by related companies prior to that date a valid registration? The question breaks into two parts: ( $I$ ) where the related company situation existed prior to any registration and (2) where it arose after a registration. In the latter case, the application to register was certainly a proper one, and, provided the use by related companies came within the common-law provisions, there is no question of the propriety of the relation-

\footnotetext{
${ }^{48}$ See $\$ 33$ of the Lanham Act, 6o STAT, 438, I5 U. S. C. \$III5, and particularly $\$ 33(b)(7), 60$ STAT. 438 , 15 U. S. C. $\$ 11 \times 5$ (b) (7).

4D Rules of Practice in Trade-Mark Cases, supra note 45, at I3.

${ }^{20}$ Schneider v. Bramson, I6 F. Supp. 493 (E. D. N. Y. 1936); Continental Corp. v. National Union Radio Corp., 67 F. $2 d 938$ (C. C. A. 7th 1933); Empire Crafts Corp. v. National Silver Company, 60 F. Supp. 1020 (S. D. N. Y. I945).
} 
ship. In the former situation, that is, where a related company relationship was in existence prior to any application to register, was the application which recited exclusive use by the applicant proper? The decisions indicate that such application was proper, because they imply that the use of the mark was the use of the applicant. $^{51}$ Therefore, the claim of exclusive use in the application was proper.

However, where a related-company situation exists and an application is filed under the Lanham Act, it should be filed in due compliance with the "related company" provisions. Where a related-company situation existed prior to July 5, I947 (with or without non-Lanham Act registrations), the preferable (but not obligatory) procedure is to file a new related-company application to disclose to the Patent Office, and to the courts, the actual situation and to receive whatever benefits flow from the administrative approval of the Patent Office. ${ }^{52}$

The question arises whether a company which itself has never used a mark may apply for its registration on the basis of the use of the mark by a related company. The phrase "such use shall inure to the benefit of the registrant or applicant for registration"53 appears to determine that question in the affirmative. Rule 7.8 of the Patent Office clearly indicates that it considers this a correct interpretation, and it is submitted that this is the proper determination.

\section{Proposed Amendment}

Many suggestions for amendments to the Lanham Act have been made. One valuable suggestion is that Section 5 and the definitions of "related company" be deleted from the Act and the following substiuted:54

\section{Controlled USE by Others}

Sec. 5. Whenever anyone controls the use of a mark by one or more other persons, the controller and the persons subject to said control may be considered a single entity under this Act, and any member of this entity may be the applicant or registrant: Provided, that the controller, by general ownership or control of said persons, or by supervision of the use by said persons, or by contract with said persons, lawfully controls the nature and quality of the goods or services with respect to which the mark is used.

The advocates of this amendment criticize the use of the phrase "related company" and would substitute the words "controller and the persons subject to said control." While the suggested amendment well states the solution to the problem, and is possibly preferable language, the present provisions in the light of their historical background are adequate. It is submitted that the decision of a court or of the Patent Office would be the same under either the Lanham Act or the suggested amendment.

\footnotetext{
${ }^{61}$ See particularly the quoted language from the Bacardi case, stipra.

s2 Registration notices published in the Official Gazetfe do not indicate that a mark is filed under the "related company" provisions. The registration itself, and soft copies thercof, do so indicate. If an opposition is thought desirable, the "file wrapper" will indicate the exact situation to the opposer.

${ }^{53}$ Sec. 5 of the Lanham Act, 60 Stat. 429, I5 U. S. C. \$1055 (I946).

54 Report of the Trade Mark Commttree of the Patent Law Association of Chicago it-it (r948).
} 


\section{SUMmary}

The "related company" provisions are a logical statutory summary as of 1946 of . the developing common law on "controlled licensing." The fundamental requirement that the public be not deceived has confirmation in these provisions. All applications to register and all contracts setting forth the relationship between related companies should be most carefully prepared. In the light of Judge O'Connell's dissent in the Celanese case and the decision in the Fisk case, day-to-day observance of the provisions of related-company contracts should be specifically enforced. 